\title{
PHYSIOLOGICAL AND PRODUCTIVE RESPONSES OF ENVIRONMENTAL CONTROL ON HOUSED SOWS
}

\author{
Carlos Eduardo Bites Romanini; Yamilia Barrios Tolon²; Irenilza de Alencar Nääs²*; Daniella \\ Jorge de Moura ${ }^{2}$ \\ ${ }^{1}$ UNICAMP/FEAGRI - Programa de Pós-Graduação em Engenharia Agrícola. \\ ${ }^{2}$ UNICAMP/FEAGRI, C.P. 6011 - 13083-970 - Campinas, SP - Brasil. \\ *Corresponding author <irenilza@agr.unicamp.br>
}

\begin{abstract}
Swine housing must promote an adjusted environment for thermal comfort and high animal productivity without negatively affecting the sow performance and reproductive response. This study evaluated the use of distinct environmental cooling equipments on sow performance, both on the gestation and on nursing in open sided housing. Two treatments were tested in the gestation building: natural ventilation and mechanical ventilation associated to fogging; while in the nursing rooms three treatments were tested: natural ventilation; mechanical ventilation; and evaporative cooling with forced ventilation. Sows were randomly chosen from the same genetic lot form six combined treatments. The evaporative cooling system in the farrowing room differed for piglet performances, at birth (4\% higher) and on daily weight gain (15\% higher), and also for sow physiological response improving the respiratory rate (8\%) and back fat thickness (3\%), without influencing skin temperature. The use of evaporative cooling directed to the sow head during nursing improved the physiological and productive results.
\end{abstract}

Key words: gestating sows, lactating sows, thermal stress

\section{RESPOSTAS FISIOLÓGICAS E PRODUTIVAS DO CONTROLE AMBIENTALEM FÊMEAS SUIINAS ALOJADAS}

\begin{abstract}
RESUMO: As instalações suínicolas devem promover um ambiente adequado para o conforto térmico, sem afetar negativamente o desempenho produtivo e reprodutivo das porcas. O presente trabalho avaliou a influência do uso de diferentes equipamentos de climatização, em ambas as instalações abertas de gestação e maternidade, no desempenho das matrizes suínas. Na instalação de gestação foram testados dois tratamentos: ventilação natural e resfriamento; enquanto nas salas de maternidade foram aplicados três tratamentos: ventilação natural, ventilação mecânica e resfriamento adiabático com ventilação forçada. Matrizes escolhidas aleatoriamente, com a mesma genética, foram expostas a seis tratamentos combinados. O sistema de resfriamento adiabático na maternidade foi diferencial para o desempenho dos leitões ao nascer (4\% superior) e no ganho de peso diário (15\% superior), e também para as respostas fisiológicas das porcas com melhorias nos resultados de freqüência respiratória (8\%) e espessura de toucinho (3\%). Não houve influência na temperatura de pele dos animais. O uso de resfriamento evaporativo direcionado para a cabeça das porcas na maternidade demonstrou ser um procedimento positivo com melhorias nos resultados fisiológicos e produtivos.

Palavras-chave: matrizes suínas gestantes, matrizes suínas em aleitamento, estresse térmico
\end{abstract}

\section{INTRODUCTION}

Since the 1960's there have been significant changes in swine housing and management to improve production related to restrictions on animal movement, social interactions, thermal comfort, and welfare (Esmay, 1969; Pinheiro et al., 2002; Tolon, 2002). Current knowledge states that appropriate housing should meet the physiological needs of sows (Rapp et al., 1988; Turner et al., 1998; Bridges et al., 1998; Nääs, 2000).
High temperatures affect swine performance, which can be evaluated by physiological response (Curtis, 1983; Perdomo, 1994; Banhazi et al., 2000). When subjected to heat stress sows tend to decrease productivity by reducing feed consumption; reduce reproductive efficiency (Love, 1978; Love, 1981); deliver less piglets (Domínguez, et. al., 1996), and present low performance of piglets at weaning (Mount, 1974; Quiniou \& Noblet, 1999; Sousa, 2002; Tolon, 2002; Brown-Brandl \& Eigenberg, 2000). Adult sows are more resistant to cold than to excessive heat exposure, 
benefiting from the use cooling acclimatization in housings (Curtis, 1983; Nääs, 2000; Barbari \& Guerri, 2005).

Environmental control alleviates heat stress improving productive responses (Müller, 1982; Bortolozzo et al., 1997; Hannas, 1999). Reduction of the heat load can be achieved by properly designed ventilation and cooling systems, in both gestating and nursing housing (Bull et al., 1997; Gates et al., 1991a). Room evaporative cooling and head ventilation systems help reducing the negative effects of high temperatures in farrowing rooms (Dong et al., 2001; Barbari \& Guerri, 2005). Misting systems are lower in efficiency when compared to conventional pad systems (Roller \& Goldman, 1969; Bottcher et al., 1991) but the equipment noise may cause animal agitation (Barbari \& Guerri, 2005). Thermal index evaluation in swine confinement has been used to identify regions suitable for a particular housing design (Turner et al., 1998).

This research aimed to identify and measure physiological and productive responses of sows exposed to distinct environmental cooling systems both in gestating and farrowing houses.

\section{MATERIAL AND METHODS}

This study was carried out from October 2004 to March 2005 in a commercial swine farm near Campinas, São Paulo State, Brazil $\left(47^{\circ} 05^{\prime} \mathrm{W}, 22^{\circ} 54^{\prime}\right.$ $\mathrm{S}$, altitude of $640 \mathrm{~m}$ ), with SE prevailing winds. Local daily average summer dry bulb temperature was $27.5^{\circ} \mathrm{C}$ and $83 \%$ relative humidity, while winter mean values were $13.3^{\circ} \mathrm{C}$ and $68 \%$ respectively.

The open sided gestating building was $10 \mathrm{~m}$ wide, $50 \mathrm{~m}$ long, $3 \mathrm{~m}$ high, and the long axis was EastWest oriented, having natural ventilated opened sidewalls, with a fiber-cement roof painted white inside and outside, and the floor and walls were made of masonry. Sows were kept in metallic crates from pregnancy to seven days prior to delivery. In this building the sows were exposed to two treatments: T1 = natural ventilation and $\mathrm{T} 2=$ cooling system (mechani- cal ventilation with two axial $372.8 \mathrm{~J} \mathrm{~s}^{-1}$ fans, associated to fogging with ten fogging nozzles operating with $6.910^{6} \mathrm{~Pa}$ pressure and $7 \mathrm{~L} \mathrm{~h}^{-1}$ distributed in two pipelines). The temperature for the fans to initiate was $25^{\circ} \mathrm{C}$ and for the fogging systems was $27^{\circ} \mathrm{C}$.

The nursing room in the building was 12.5 $\mathrm{m}$ long, $10 \mathrm{~m}$ wide and $3 \mathrm{~m}$ high, covered with metallic tile roof painted white with walls made of concrete bricks covered with mortar and painted white, and had fourteen individual pens (each $1.7 \mathrm{~m}$ wide and $2.8 \mathrm{~m}$ long). In this housing three environment control treatments were evaluated: T3 = natural ventilation (the walls were $1.7 \mathrm{~m}$ high with lateral openings of $1.3 \mathrm{~m}$ width and 12.5 length); T4 = mechanical ventilation (one axial $372.8 \mathrm{~J} \mathrm{~s}^{-1}$ fan); T5 = evaporative pad cooling with forced ventilation equipment (745.7 $\mathrm{J} \mathrm{s}^{-1}$ ). The equipment pumped the cooled air through a $0.15 \mathrm{~m}$ PVC pipe directly $0.40 \mathrm{~m}$ above sow heads.

The sows used for the experiment had the same genetics. At gestation, the animals were treated two times per day with a balanced feed (16\% of brute protein and $3.2 \mathrm{kCal}$ of metabolized energy). At farrowing the sows were under a standard lactation diet. The maximum feed intake was $6 \mathrm{~kg} \mathrm{day}^{-1}$. One hundred and twenty six sows that were previously under treatments $\mathrm{T} 1$ or T2 were randomly chosen. These sows were equally distributed to three farrowing rooms (T3, T4 or T5). Table 1 shows the treatments Ti-j combined where $i$ represents the treatment in the gestation phase and $j$ the treatment in the nursing stage.

Climatic data inside both gestation and nursing rooms were collected using data loggers. Skin temperature (ST) on the back of the sows was daily measured at $10 \mathrm{~h} 00$ using an infra red thermometer, and the back fat thickness (BFT) was measured using a digital equipment, approximately at the $10^{\text {th }} \mathrm{rib}, 6 \mathrm{~cm}$ from the middle back line, in all sows at entering and leaving each treatment in the nursing house. The respiration rate (RR) was recorded for the nursing sows through the observation of the number of flank move-

Table 1 - Treatments distribution in the experiment.

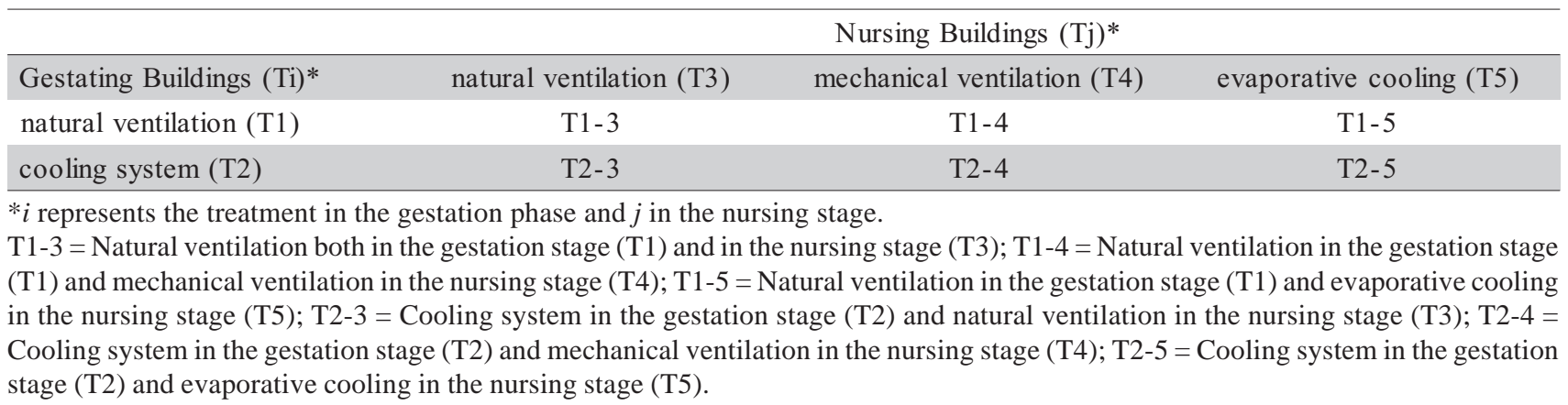


ments per minute, with three replicates between $10 \mathrm{~h} 00$ e $11 \mathrm{~h} 00$. The piglets were weighed at birth and weaning (21 days).

Descriptive and statistical analysis of mean comparison using the Tukey test was performed using the Minitab ${ }^{\circledR}$ software.

\section{RESULTS AND DISCUSSION}

A direct correlation was found between piglet live weight and the heat loss to the environment by the sows in the nursing building. The more comfortable the sows were the better the piglet performance was, as already pointed in the literature (Mount, 1974; Hannas, 1999; Nääs, 2000; Pinheiro et al., 2002).

The best result of total weight gain at weaning $(6.27 \mathrm{~kg})$ as well as the average daily gain $(0.32$ $\mathrm{kg}$ day $^{-1}$ ) were found for sows housed under natural ventilation at the gestation building (T1) and had evaporative cooling in the nursing house (T5) (Table 2). Similar results were found by Nunes et al. (2003), who registered a better environmental condition at the gestation housing with a forced ventilation system. Nevertheless this system was not sufficient to change sow reproductive efficiency. The evaporative cooling system in the farrowing room was determinant for piglet performance. These results are in accordance with Wagenberg et al. (2006), who showed that cooling the floor under the sow shoulder using a farrowing crate increased piglet performance (22 $\mathrm{g}_{\text {day }}{ }^{-1}$ per piglet, $9 \%$ higher than in the ordinary system). Similar results were found by Tavares et al. (2000) who recorded lower weight gain under heat stress, even though the carcasses were not affected, as well as Nääs (2000) got analogous results when observing the increase of productivity of sows housed in the same region during the cooler months of the year.

Even though expected from literature data, the best performance of the combined treatment T2-5, indicates that the forced ventilation system (T2) used during the gestation housing did not influence piglet performance (Table 2). Probably the position of the fans and consequently the air flow distribution had negative effect on the forced ventilation system efficiency in the gestation room. The treatment using natural ventilation (T1-3) produced the lowest piglet weight gain (Table 1), in agreement with Wagenberg et al. (2006).

Mean values of ST, RR and BFT are shown in Table 3, which were measured in order to estimate thermal comfort. The sensible thermal losses decrease with heat stress exposure, and a change in skin temperature was expected as mentioned by Brown-Brandl \& Eigenberg (2000), Yan \& Yamamoto (2000), and Brown-Brandl et al. (2004). This fact was however not observed, probably due to the fact that all authors

Table 2 - Results of piglet performance during lactation.

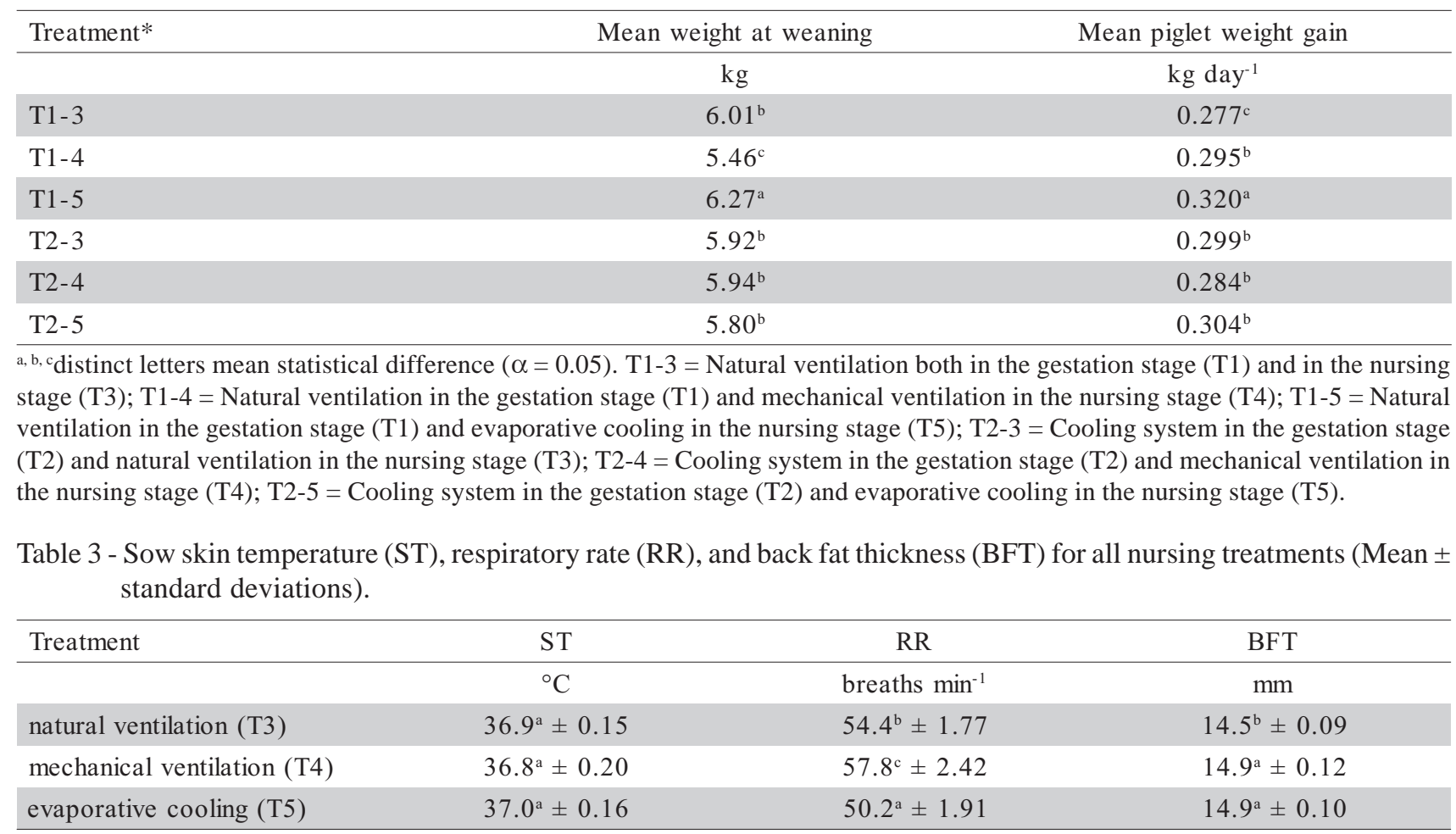

a, b, cdistinct letters mean statistical difference $(\alpha=0.05)$ for each column. 
Table 4 - Mean environmental variables during the experiment inside the gestation and farrowing housing, and outside.

\begin{tabular}{llcc}
\hline & \multicolumn{1}{c}{ Treatment } & Temperature & Relative Humidity \\
\hline \multirow{3}{*}{ Gestation } & & ${ }^{\circ} \mathrm{C}$ & $\%$ \\
& & 24.8 & 72.0 \\
& natural ventilation (T1) & 22.3 & 73.7 \\
\multirow{2}{*}{ Nursing } & cooling system (T2) & natural ventilation (T3) & 75.0 \\
& mechanical ventilation (T4) & 25.0 & 76.1 \\
\hline Outside & evaporative cooling (T5) & 24.3 & 92.5 \\
\hline
\end{tabular}

worked in controlled environments, while this present study was carried out in a swine farm; exposed to the local climatic parameters (Table 4). The difference was not in favor of the evaporative cooling system $\left(37^{\circ} \mathrm{C}\right.$, higher average of skin temperature). These results were representative of the animal back, while the evaporative cooling system was directed to the sow head.

The lowest value in respiratory rate was found for the nursing treatment T5 (50.2 breaths $\mathrm{min}^{-1}$ ) and the highest for $\mathrm{T} 4$ ( 57.8 breaths $\mathrm{min}^{-1}$ ), showing a distinct effect on the respiratory rate of the animals as a function of the environmental conditions, as suggested by Yan \& Yamamoto (2000). The results also differ in part from Hannas (1999), who found that the respiratory rate is the first response of animals when exposed to thermal stress. The respiratory rate for the forced ventilation system (T4) in the farrowing room were probably affected by the high restlessness of the animals associated to a high noise level of the fan in this treatment, when compared to the natural ventilation system treatment (T3). The results were similar to those obtained by Gates et al. (1991b) and Bull et al. (1997) who found that growing-finishing swine as well as sows present highest performance when housed in an environment with evaporative cooling, when compared to both misting and mechanical ventilation systems.

When exchanging heat by conduction swine reach the thermal neutral balance and their respiratory rate tends to become normal, even after exposure to acute heat stress (Bridges et al., 2000; Brown-Brandl \& Eigenberg, 2000). Under treatments T3 (natural ventilation) and T4 (mechanical ventilation) the sows presented a certain degree of heat stress exposure, in agreement to Esmay (1969). Tavares et al. (2000), evaluating the effect of heat stress on swine performance concluded that the respiratory rate increased considerably when the environmental temperature was above $26^{\circ} \mathrm{C}$, which is above the thermal comfort zone.

Results on back fat thickness (Table 3) point to difference between treatments, and both treatments $\mathrm{T} 4$ and T5 presented the best result $(14.9 \mathrm{~mm})$, in which the evaporative cooling system (T5) had the lowest variation. These results follow the same trend found by Derno et al. (1995), they however conflict with the results found by Quiniou et al. (2000), who did not find variations in back fat thickness due to change in environmental conditions. This indicates the possibility that the most effective acclimatization systems used during nursing were those that used forced ventilation. In this study there was no change in the room temperature, however the wind speed had a positive effect in alleviating heat stress by increasing the upper limits of the critical temperature during the nursing stage, and influencing the results of back fat thickness, as pointed out by Aherne \& Foxcroft (2000).

\section{CONCLUSIONS}

Considering piglet performance at weaning as well as the measured physiological response of the sows, the treatment that presented the most effective combination for alleviating heat stress was the use of natural ventilation in gestating buildings, associated to evaporative cooling directed to the sow head during nursing. The use of this type of cooling device represents a positive investment since it results in both the highest piglet mean daily weight gain and total weight at weaning.

\section{ACKNOWLEDGEMENTS}

To FAPESP, for supporting this research.

\section{REFERENCES}

AHERNE, F.; FOXCROFT, G. Manejo da leitoa e da porca primípara. Parte V. Manejo nutricional na gestação e lactação. In: SIMPÓSIO INTERNACIONAL DE REPRODUÇÃO E INSEMINAÇÃO ARTIFICIAL EM SUÍNOS, 7., Foz do Iguaçu, 2000. Anais. Campinas: Animal World, 2000. p.145-165.

BANHAZI, T.; CARGILL, C.; HARPER, Z.; WEGIEL, J.; GLATZ, $P$. The effects of adverse environmental and drinking water temperatures on pig production: final report. Canberra: PRDC, 2000. 19p.

BARBARI, M.; GUERRI, F.S. Cooling systems for heat protection of farrowing sows. In: INTERNATIONAL LIVESTOCK ENVIRONMENT SYMPOSIUM, 7., St. Joseph, 2005. Proceedings. Beijing: ASABE, 2005. p.122-129. 
BORTOLOZZO, F.P.; WENTZ, I.; BRANDT, G.; NOBRE JÚNIOR., A. Influência da temperatura corporal sobre a eficiência reprodutiva em fêmeas suínas. In: CONGRESSO BRASILEIRO DE VETERINÁRIOS ESPECIALISTAS EM SUÍNOS, Foz do Iguaçu, 1997. Anais. Chapecó: Abraves, 1997. p.281-282.

BOTTCHER, R.W.; BAUGHMAN, G.R.; GATES, R.S.; TIMMONS, M.B. Characterizing efficiency of misting systems for poultry. Transactions of the ASAE, v.34, p.586-590, 1991.

BRIDGES, T.C.; TURNER, L.W.; GATES, R.S. Economic evaluation of misting-cooling systems for growing-finishing swine through modeling. Applied Engineering in Agriculture, v.14, p.425430, 1998.

BRIDGES, T.C. Swine performance enhancement with cooling as influenced by summer growth period and weather. In: SWINE HOUSING INTERNATIONAL CONFERENCE, 1., Des Moines, 2000. Proceedings. St. Joseph: ASAE, 2000. p.348-356.

BROWN-BRANDL, R.A.; EIGENBERG, J.A. Acute heat stress effects on total heat production, respiration rate, and core body temperature in growing-finishing swine. In: INTERNATIONAL MEETING OF THE AMERICAN SOCIETY OF AGRICUlturAL ENGINEERS, Milwaukee, 2000. Proceedings. St. Joseph: ASAE, 2000. p.8.

BROWN-BRANDL, T.M.; NIENABER, J.A.; XIN, H.; GATES, R.S. A literature review of swine heat and moisture production. Transactions of the ASAE, v.47, p.259-270, 2004.

BULL, R.P.; HARRISON, P.C.; RISKOWSKI, G.L.; GONYOU, H.W. Preference among cooling systems by gilts under heat stress. Journal of Animal Science, v.78, p.2078-2083, 1997.

CURTIS, S.E. Environmental management in animal agriculture. Ames: Iowa State University Press, 1983. 409p.

DERNO, M.; JENTASCH, W.; HOFFMANN, L. Effect of long time exposure to different environment temperatures on heat production of growing pigs. Livestock Production Science, v.43, p.149-152, 1995.

DOMINGUEZ, J.C.; PENA, F.J.; ANEL, L.; CARBAJO, M. Swine summer infertility syndrome in north west Spain. Veterinary Record, v.27, p.39-94, 1996.

DONG, H.; TAO, X.; LIN, J.; XIN, H. Comparative evaluation of cooling systems for farrowing sows. Applied Engineering in Agriculture, v.17, p.91-96, 2001.

ESMAY, M. L. Principles of animal environment. Westport: AVI Publishing, 1969. 325p.

GATES, R.S.; USRY, J.L.; NIENABER, J.A.; TURNER, L.W.; BRIDGES, T.C. Optimal misting method for growing-finishing hogs. Transactions of the ASAE, v.34, p.2199-2206, 1991a.

GATES, R.S.; TIMMONS, M.B.; BOTTCHER, R.W. Numerical optimization of evaporative misting systems. Transactions of the ASAE, v.34, p.575-580, 1991b.

HANNAS, M.I. Aspectos fisiológicos e a produção de suínos em clima quente. In: SILVA, I.J.O. Ambiência e qualidade na produção industrial de suínos. Piracicaba: FEALQ, 1999. $247 p$.

LOVE, R.J. Definition of a seasonal infertility problem in pigs. Veterinary Record, v.103, p.443-446, 1978.

LOVE, R.J. Seasonal infertility in pigs. Veterinary Record, v.109, p.407-409, 1981.

MOUNT, L.E. The concept of thermal neutrality. In: MONTEITH, J.L; MOUNT, L.E. Heat loss from animals and man. London: Butterworths, 1974. p.425 439.

MÜLLER, P.B. Bioclimatologia aplicada aos animais domésticos. 2 ed. Porto Alegre: Sulina, 1982. 183p.
NÄÄS, I.A. Influência do ambiente na resposta reprodutiva de fêmeas. In: SIMPÓSIO INTERNACIONAL DE REPRODUÇÃO E INSEMINAÇÃO ARTIFICIAL EM SUÍNOS, Foz de Iguaçu, 7., 2000. Proceedings. Concórdia: Embrapa Suínos e Aves, 2000. p.253-262.

NUNES, C.G.V.; COSTA, E.P.; OLIVEIRA, R.F.M.; DONZELE, J.L.; NUNES, R.V.; CARVALHO, G.R. Efeito do acondicionamento térmico ambiental sobre o desempenho reprodutivo de fêmea suína. Revista Brasileira de Zootecnia, v.32, p.854-863, 2003.

PERDOMO, C.C. Conforto ambiental e produtividade de suínos. In: SIMPÓSIO LATINO-AMERICANO DE NUTRIÇÃO DE SUÍNOS, São Paulo, 1994. Anais. São Paulo: CBNA, 1994. p.19-26.

PINHEIRO, J.P.; GALVÃO, R.J.D.; NETO, F.B.; ESPINDOLA, G.B. Características reprodutivas de suínos puros na região semiárida do Rio Grande do Norte. I. Tamanho da leitegada. 2002. Available at: www.porkworld.com.br/trabalhos tecnicos/ natimortalidadeemsuínos.html. Accessed 18 Aug. 2003.

QUINIOU, N.; NOBLET, J. Influence of high ambient temperatures on performance of multiparous lactating sows. Journal of Animal Science, v.77, p.2124-2134, 1999.

QUINIOU, N.; GAUDRE, D.; RAPP, S.; GUILLOU, D. Effect of ambient temperature and diet composition on lactation performance of primiparous sows. Journées de la Recherche Porcine en France, v.32, p.275-282, 2000.

RAPP, D.L.; FROELICH, D.P.; JULSON, J.L.; WOERMAN, R. Zone and drip cooling comparisons for lactating swine. Transactions of the ASAE, v.31, p.1774 1781, 1988.

ROLLER, W.L.; GOLDMAN, R.F. Response of swine to acute heat exposure. Transactions of the ASAE, v.12, p.164-174, 1969.

SOUSA, P. Estudo do ambiente de porcas em gestação utilizando recursos de aclimatação. Campinas: UNICAMP/Faculdade de Engenharia Agrícola, 2002. 112p. Tese (Doutorado).

TAVARES, S.L.S.; DONZELE, J.L.; OLIVEIRA, R.F.M.; FERREIRA, A.S. Influence of environment temperature on the performance and the physiological traits of barrows from 30 to $60 \mathrm{~kg}$. Revista Brasileira de Zootecnia, v.29, p.199-205, 2000.

TOLON, Y.B. Avaliação do ambiente gerado pelo resfriamento adiabático em maternidade de suínos e determinação de modelos de previsão de parâmetros de conforto. Campinas: UNICAMP/ Faculdade de Engenharia Agrícola, 2002.117p. Tese (Doutorado).

TURNER, L.T.; BRIDGES, C.; COFFEY, R.; GATES, R.S.; PARKER, G.; BROWN BRANDL, T.; OVERHULTS, D. Comparison of observed and simulated grow-finish swine performance under summer conditions. Applied Engineering in Agriculture, v.14, p.419-423, 1998.

WAGENBERG, A.V.; SCHWERING, P.; BINNENDIJK, G.P.; CLAESSEN, P.J.P.W. Effect of floor cooling on farrowing sow and litter performance: field experiment under Dutch conditions. Transactions of the ASABE, v.49, p.1521-1527, 2006.

YAN, P.S; YAMAMOTO, S. Relationship between thermoregulatory responses and heat loss in piglets. Animal Science Journal, v.71, p.505-509, 2000.

Received December 11, 2006

Accepted November 29, 2007 